\title{
Analysis of Economy and Trade among China, India, and Russia under the Belt and Road Initiative
}

\author{
Jui-Lung Chen ${ }^{1}$, Hsiung-Shen Jung ${ }^{2}$ \\ ${ }^{1}$ Department of Business Administration, National Chin-Yi University of Technology, Taiwan, R.O.C. \\ ${ }^{2}$ Department of Applied Japanese, Aletheia University, Taiwan, R.O.C. \\ Correspondence: Jui-Lung Chen, Department of Business Administration, National Chin-Yi University of \\ Technology, Taiwan.
}

Received: September 26, 2019

Accepted: November 6, 2019

Online Published: November 8, 2019

doi:10.5539/ibr.v12n12p1

URL: https://doi.org/10.5539/ibr.v12n12p1

\begin{abstract}
The Belt and Road Initiative advocated by China is expecting to assist in the infrastructure and financing of participating countries and promote free trade through cooperation with countries along the Belt and Road. China hopes to lead the regional economic integration process through investment-driven trade. Out of geopolitical considerations, Russia and India initially held a relatively negative or cautious attitude towards the Belt and Road Initiative. Therefore, Russia proposed the concept of the Eurasian Economic Union (EEU) in 2011 in order to unite the other independent ASEAN countries based on the customs alliance consisting of Russia, Belarus, and Kazakhstan, and thus create a supranational consortium, which in turn have the ability to compete and cooperate with the Belt and Road Initiative proposed by China. In 2014, India launched the Indian version of the Belt and Road Initiative, named Project Mausam, expecting to promote the integration of economic and trade exchanges around the Indian Ocean with India as the center. However, after recent strikes by the trade war, China actively seeks assistance from India and Russia in order to break through the US trade blockade. During the G20 summit held in Japan in June 2019, China, India, and Russia held a three-party talk. After the talk, the three countries issued a joint statement claiming that "they shall undertake more global responsibilities to protect the fundamental and long-term interests of the three countries themselves and the world", which seems to have opened up opportunities for future cooperation among the three countries. Therefore, this paper explores the competitive and cooperative relationship among China, India, and Russia under the Belt and Road Initiative.
\end{abstract}

Keywords: Belt and Road Initiative, Eurasian economic union, project Mausam

\section{Introduction}

The Belt and Road Initiative is the response of China to its slowing economic growth in recent years. China expects to enhance its global economic and trade status and political influence through international economic cooperation. As the Belt and Road Initiative spreads across Europe, Asia, and Africa, China can integrate the economic interests of many countries along the strategic path and hopes to resolve the dilemmas of domestic excess capacity and fund idling. In particular, the Belt and Road Initiative can help China achieve the military purpose of expanding overseas military bases or deploying submarines in the Arctic Circle, which serves as an important strategy for economic, political, and military considerations. The promotion of the Belt and Road Initiative guided by the Belt and Road Initiative, and supplemented by the Asian Infrastructure Investment Bank (AIIB) and the Regional Comprehensive Economic Partnership (RCEP). As the policy will bring considerable economic benefits to the countries along the path if it is implemented smoothly, most countries show a welcome attitude. However, in the early stage, Russia located along the Belt and India located along the Road held a mixed attitude toward China's promoting the Belt and Road Initiative, concerned while reserved. However, as recently hit by the trade war, China has actively sought assistance from India and Russia to break through the US trade blockade. China, India, and Russia held a three-party talk at the G20 summit in June 2019, which seems to have opened up opportunities for future cooperation among the three countries. If China hopes to cooperate with India and Russia, it must break away from its political considerations, connect with the countermeasures against Russia and India through economic means, and thus create a mutually beneficial environment.

Different from the previous "Western China Development" policy which aims to balance the domestic regional 
economic development and improve the overall national strength, the Belt and Road Initiative involves the political and economic interests of many countries. The threat of rising China results in a sense of cautious fear to the United States and the world. Russia located to the north of China and India located to the south of China are both directly affected by the Belt and Road Initiative, and can directly affect the Belt and Road Initiative. Especially, under the great influence of Russia on the five Central Asian countries and the great influence of India on the Association of Southeast Asian Nations, the success of the Belt and Road Initiative in these two blocks is related to the westward expansion success of the Belt and Road Initiative. Therefore, China's relationship with Russia and India as well as the countries in the above two blocks is the key to the Belt and Road Initiative and also an observational focus of this study.

\section{Literature Review}

According to Li (2015), there have been various Silk Road development plans around the world. For example, the New Silk Road Initiative advocated by the US Government originated from the New Silk Road proposed by Professor Frederick Star, and was originally based on the concept of the "Greater Central Asia Plan" proposed by the United States; New Silk Road Initiative was a cross-regional economic plan formally proposed by former US Secretary of State Hillary Clinton in July 2011, and aimed to help Afghanistan integrate into the Central Asian region by rebuilding various infrastructures, and thus create an economic circle to connect the Central Asian region and the South Asian region centered on Afghanistan to contribute to realizing the strategic goals of southward energy transmission and northward commodity transportation. The "Asia-Europe Silk Road" of Japan aimed to connect Japan with Turkey to curb the development of China, but the Japanese version of the "New Silk Road" lacked a trade route between Asia and Europe; the "Eurasia Economy Union" proposed by Russia focused on the revival of Russia. Du and Ma (2015) pointed out that the strategic fulcrum of the Belt and Road Initiative is as follows: the South China Sea and the surrounding region is the strategic base of the Maritime Silk Road; Myanmar and Pakistan are the eastern and western anchors of the Maritime Silk Road; Central Asia and Russia are the commercial throats and bridges of the Land Silk Road. The Chinese version of the Silk Road Economic Belt is targeted at implementing the "two routes and one road" planning model, which refers to developing the "north route" based on the coordination of Uzbekistan, Kazakhstan, and Russia, and the "south route" based on the cooperation of Kyrgyzstan, Turkmenistan, and Iran. The north route focuses on the cooperation in traditional energy resources and new energy resources while the south route is supported by industries and emphasizes the infrastructure investment. As a result, the two routes make full use of their advantages and competitiveness. The other one road mainly focuses on the "energy channel", namely the Eurasia Energy Channel, which highlights the locational and capacity advantages of Central Asia, develops the cooperation of oil and gas resources, and gradually rises to a new industrial belt consisting of new energy resources and environmental cooperation $(\mathrm{Li}, 2015)$.

Russia is a transit country with great strategic value. Considering the continued turmoil in the Middle East and Transcaucasia, the transportation artery of the Belt and Road Initiative across Russia has been given a vital significance. Although Moscow is not a market target for the Belt and Road Initiative, the sanctions imposed by the United States and the European Union on Russia have made people re-recognize the importance of the Russian market: the consistently hostile economic policies of the European Union and the United States toward Russia have increased the risk of China being isolated by the US-led international economic system. China needs to cooperate with Russia while the sanctions of Western countries against Russia provide a broad market for Chinese commodities. On the one hand, the Silk Road Economic Belt is beneficial for resolving the difficulties which Russia faces in its Far East Development Plan. As nothing can replace pragmatism in Central Asia, Kazakhstan and Russia may seek to establish a balanced relationship with China and other participants in the region for the purpose of stability. Kazakhstan can benefit from the Belt and Road Initiative (Lu and Wang, 2016). Chen (2015) pointed out that India believes that accepting the Belt and Road Initiative is conducive to its economic construction. On the other hand, India believes that the Belt and Road Initiative promoted by China is an investment-driven regional engagement strategy: on the economic level, it can expand China's influence in the surrounding regions through investment; on the diplomatic level, it contributes to shaping China's positive image in the global community; on the security level, it is capable of partially offsetting the military pressure exerted by the Asia-Pacific Rebalancing Strategy launched by the Obama administration; on the strategic level, it can guarantee the safety of China's energy import channel. In addition, the unique mentality and pride of great power long held by India make it easy for India to take a zero-sum gaming perspective toward the Sino-Indian interaction. It believes that China's rising influence in the Indian Ocean region will directly lead to a decline in the leadership of India in the region. As pointed out by Indian scholars, India regards the 21 st Century Maritime Silk Road as a symbol of Chinese nationalism. Moreover, India even launched the Project Mausam in June 2014 
in order to counter the Belt and Road Initiative. On the Belt and Road Initiative International Cooperation Summit held in Beijing on May 14, 2017, India also protested against China's incorporating the China-Pakistan Economic Corridor resulting from the cooperation between China and Pakistan into the Belt and Road Initiative, and was absent as it planned to construct dams in the Kamil area at the center of India-Pakistan sovereignty dispute.

According to World People News (2017, May 18), India believes that China is trying to indirectly dominate the foreign policies of the related countries through economic assistance, infringe on their national sovereignty and territorial integrity. As the China-Pakistan Economic Corridor resulting from the cooperation between China and Pakistan passes through the disputed area between India and Pakistan, it has decided to boycott the corridor and promote the "free corridor" with Japan. In addition, it plans to invest in the development of ports in Africa, Sri Lanka, Iran and Southeast Asia in order to counter the Belt and Road Initiative, and balance China's influence in relevant regions. Chen (2013) believed that factors affecting the foreign policies of India can be roughly categorized into domestic and international factors. For India, the internal factors include territorial disputes: (Southern Tibet, small undemarcated areas in the middle, Aksai Chin Saiqin area), historical issues (the defeat of India in the Sino-Indian border war in 1962, the resulting feeling of stigma and betrayal by China has continued to this day.), trade imbalances (China enjoys huge trade surplus); the external factors involve the geopolitical strategies of India and the relationship of China and India with other small South Asian countries. For example, China assisted Pakistan in the construction of the Gwadar Port project, invested in the Chittagong Deepwater Port, the construction of projects in Bangladesh, and the reconstruction of the Hambantota Port, Sri Lanka, etc., as well as leased the offshore islands of Myanmar as a radar station and military base. Meng (2017) proposed that the four long-lasting mentalities of India have largely constituted the basis of India's national policies, which will determine the success or failure of India's dream of becoming a great power. The four mentalities include: (1) The proud posture of a great power that cannot be put down; (2) the complex emotion toward China that cannot be understood; (3) the dissatisfied psychology that cannot be faded; (4) the political correctness that cannot be driven away. Furthermore, he analyzed the motivations for India's provocation in Dong Lang Village as follows: (1) Intend to transfer the focus on domestic conflicts, enhance the national spirits, and unite the people; (2) attempt to strengthen or maintain its control and influence on neighboring countries in South Asia; (3) try to gain international support and compassion; (4) plan to create trouble for China, and increase its bargaining chips; (5) seek military adventure and strategic gambling.

\section{Research and Analysis}

As the success of reform and opening-up has laid the foundation for the rise of China, the Belt and Road Initiative is another important policy that China extends to the west. The Belt and Road Initiative is proposed to provide economic assistance for the small and medium-sized countries along the path. Most of these countries are optimistic about the Belt and Road Initiative, especially the five Central Asian countries along the Belt and the Association of Southeast Asian Nations along the Road. However, when it comes to Russia and India which hold a mixed attitude toward the Belt and Road Initiative, China may need to seek a solution that benefits both of them. First, this study analyzes the relationship between China, India, and Russia from a historical perspective to investigate how Russia and India respond to the Belt and Road Initiative.

\subsection{Impact of the Belt and Road Initiative on the Sino-Russian Political and Economic Relationship}

Sino-Russian relationship is sometimes close and sometimes tense just as the relationship between lip and mouth. Initially, during the one-sided period, the two countries were closely related and mutually dependent; the Soviet Union provided a large amount of economic assistance to China while China was politically standing along the Soviet Union to confront the United States. At that time, the Sino-Soviet relationship was in an excellent state. After the implementation of the Great Leap Forward, conflict emerged between the two countries, which changed the relationship between the two countries. From the political criticism of the Sino-Soviet debate into the Zhenbao Island Incident, the relationship between the two countries was at the tensest stage. However, as the Chinese proverb goes, "If the lips are gone, the teeth will be cold", the two countries must maintain moderate cooperation during the Cold War to fight against the third party. It was not until the Gorbachev visit to China in 1989 that the tension between the two countries was gradually resolved. But until now, China and Russia have still kept a rather subtle relationship. Whether the Sino-Soviet relationship is hostile or intimate after the economic assistance, political criticism, and military conflict is often based on the international situation or the interests of the two countries, which can be seen from Russia's seemingly agreement but also opposition toward the Belt and Road Initiative. However, Jia and Chen (2015) believed that Russia is a major energy and military power, while China rises from industrial production, and thus China and Russia share high economic complementarities. The oil and gas resources of Russia are essential for China to safeguard its energy security. In 
addition, Russia is also the main external supplier of many advanced armaments and technologies that are needed for China to enhance its national defense capabilities. For Russia, China is one of the important sources of industrial manufactured commodities. But, in response to the Belt and Road Initiative, Russia also establishes its own economy version. Specifically, the Presidents of Russia, Belarus, and Kazakhstan signed the Eurasian Economic Union Treaty in May 2014. Later, the Eurasian Economic Union was officially launched in January 2015. Afterward, Armenia and Kyrgyzstan also joined in the Eurasian Economic Union. While promoting Eurasian integration, Russia faces many external challenges from the magnetic attraction of the European Union. In particular, the launch of the Oriental Partnership Program proposed by the European Union makes the European Union more attractive. In this circumstance, some countries demonstrate a high willingness to integrate into the European Union, rather than join in the Russian-led Eurasian Economic Union. Another external challenge that Russia faces is the so-called Belt and Road Initiative proposed by China, especially the Silk Road Economic Belt Program which was advocated by the Chinese President Xi Jinping in 2013 when visiting Kazakhstan (Wei, 2017).

The first reaction to the proposal of the Belt and Road Initiative was that China intends to make an offensive westward advance from the eastern direction of the Eurasian continent to the former Soviet Union region through another integration approach that bypasses Russia, especially to expand its influence in the Central Asian region. However, on May 8, 2015, China and Russia issued the Joint Agreement between the People's Republic of China and the Russian Federation on the Construction of the Silk Road Economic Belt and the Eurasian Economic Union in Moscow, indicating that the connection process is on the right track. The two countries initiate the dialogue mechanism connecting the Silk Road Economic Belt with the Eurasian Economic Union in order to realize the economic integration of Europe and Asia, and promote the discussion among experts and scholars on the development of a common economic space (Chen, 2015) Hu et al. (2015) presented that only Russia has the conditions to jointly build the Belt and Road Initiative and is currently the best partner. As a natural opponent, the United States will spare no effort to obstruct the construction of the Belt and Road Initiative in order to maintain its global dominance.Although in the middle position, India is slightly tilted towards the United States in the short term. However, India needs to develop itself, and thus will act according to the cooperative economic interests and the communication results of the two countries. Due to the dispute in the South China Sea, the Philippines and Vietnam will stand with the United States in the short term and have a negligible promotional effect on the Belt and Road Initiative. In addition, the countries in Africa, Europe, and the Middle East with no territorial disputes will maintain a neutral status and actively participate in both the Belt and Road Initiative and the US-led economic cooperative organization, which makes them a solid force for the joint construction of the Belt and Road Initiative.Since the disintegration of the Soviet Union, Russia has established several economies to maintain its influence. The aforementioned Eurasian Economic Union, which was launched in 2015, is apparently in response to the Belt and Road Initiative. Chi and Ji (2015) pointed out that 1) the differences between the two include: (1) Regional development and cooperation models; (2) beneficiary subjects; (3) promotion methods, and that 2) the commonalities between the two include: (1) geographical similarity; (2) consistency of economic objectives; (3) coincidence of common tasks.However, Wan (2016) stated that the development of the Eurasian Economic Union mainly faces both internal and external issues. Specifically, 1) the internal issues of the Eurasian Economic Union include: (1) The establishment of a redistribution mechanism in the process of building a unified market; (2) the excessive transaction costs resulting from the non-tariff barriers; (3) the poor coordination of macroeconomic policies; (4) the difficulties in the free flow of labor force within the Eurasian Economic Union; (5) adverse impact from the accession of Kazakhstan to the WTO on the operation of the Eurasian Economic Union. 2) The external economic and trade issues of the Eurasian Economic Union include: (1) economic and trade relationships with Ukraine; (2) economic and trade cooperation with China.

Yang (2017) pointed out that Russia believes that its top priority is to strengthen the construction of the Eurasian Economic Union in order to create conditions for equal cooperation with the European Union. However, Russia's plan is unacceptable to the United States and the European Union for the reason that the United States and the European Union are very clear that this will increase the chances and bargaining chips of Russia during the negotiations. They do not recognize or accept the Eurasian Economic Union, and do not allow Russia to hinder the development of relationships between the European Union and the countries within the former Soviet Union. In their eyes, Greater Europe should not result from the merger of two mechanisms, but from the eastward expansion of the European Union. Russia should carry out various reforms as required by the United States and the European Union. Only under acceptable conditions will the European Union absorb Russia, making it a part of Greater Europe. As the two sides seriously opposed, their relationship turns cold. The European Union has implemented special policies in the energy sector starting from the implementation of the third energy package in 2011, which imposes severe restrictions on Russia. In response, Russia has set up 
protective trade barriers targeting European products. Since the Ukrainian crisis in 2014, Russia has suffered overwhelming sanctions and isolation from the United States and the European Union, which greatly pushed Russia to officially shift its national strategic focus from Greater Europe to Greater Eurasia. As a result, Russia, which is blocked in its westward expansion, has seriously considered the possibility of eastward development. Zhan (2017) claimed that the difference between the Belt and Road Initiative and the Eurasian Economic Union is that they are not fundamentally opposite, but compatible and complementary. Although the regions involved in the Belt and Road Initiative and the Eurasian Economic Union are geographically overlapping, they can develop in harmony. Therefore, it is possible to connect the Belt and Road Initiative with the Eurasian Economic Union. At the end of the 1980s, the comprehensive disintegration of the Soviet Union, and the reform and opening up of China have led to different fates of the two countries. The former has been caught in economic recession due to political shrinkage, while the latter has risen magnificently due to its prosperous economic development. Therefore, the fluctuating Sino-Russian relationship has finally calmed down. As the proposal of the Eurasia Economic Union shows that Russia has the will to revitalize its national economy, how to connect the Belt and Road Initiative with the Eurasian Economic Union has become the research direction of many scholars.

\subsection{Impact of the Belt and Road Initiative on the Sino-Indian Political and Economic Relationship}

Although the Cold War situation was formed after World War II, China and India were on their respective sides at that time, maintaining confrontation only in form. At the end of 1953, when Zhou Enlai met with the Indian government delegation, he first proposed the five principles of peaceful coexistence, including "mutual respect for territorial integrity and sovereignty, mutual non-aggression, mutual non-interference in each other's internal affairs, equality and mutual benefit, and peaceful coexistence" (Men, 2017). However, after the Tibetan religious leader Dalai Lama escaped to India in 1959 and was granted asylum by the Indian government, the relationship between two countries began to deteriorate. On one hand, China accused India of attempting to foster the Tibetan separatist forces and then cooperate with the Western world to contain China; on the other hand, India identified China's entry into Tibet as a major threat to its national security (Chen, 2009). As early as the 1990s, India launched the Act East Policy, which aimed to rapidly expand the diplomatic target of India from the Indian Ocean to the Pacific Ocean and extend its policy objectives from Southeast Asia to East Asia. In the second half of 2010, when Sino-Japanese relationships were tense due to the collision on the Diaoyu Islands, India and Japan became closer and strengthened their cooperation in the fields of politics, economy and maritime security.Both sides have an urgent desire to check and balance China and expand their geopolitical and geoeconomic influence relying on the power of the other side. They are committed to deepening their cooperation in the security and economic fields. In terms of national defense and security, China has been a long-term concern for India and Japan, which are highly concerned about the military strength of China. Regarding politics, the common political requirements of India and Japan are to become permanent members of the UN Security Council. In economic terms, India and Japan have greater appeal to each other, which demonstrates great potential for cooperation (Wei, 2013).

Lou and Zhang (2010) asserted that India is stuck into a dual mentality of both inferiority and self-esteem facing the rise of China. The shadow of the 1962 border conflict, the pressure of China's rapid economic development and the doubts about China's cooperation with small-sized South Asian countries have made India look at China with distrust, concern and even fear. In the meanwhile, India believes that it will ascend from the South Asian leader to a great power in the world, and is proud of its ancient civilization and its status as the world's largest democracy. After the Cold War, the disintegration of the Soviet Union and the external strategic adjustment of Russia, India lacks traditional allies or new partners in the world. Coupled with the domestic economic development dilemma, India started to adjust its foreign strategies in the face of a profound international transformation. The Ministry of Foreign Affairs of India first proposed the Act East Strategy in 1995, which marks the starting point of India's Act East Strategy and serves as the focus of India's Asia-Pacific strategic adjustment (Wu, 2015).Wu (2015) pointed out that the joint statement issued by the United States and India in January 2015 stated that India and the United States will actively deepen the regional interactions within the framework of the Eastward Action Policy and the Re-balancing Strategy under the guidance of the US-India Joint Strategic Vision in the Asia-Pacific and Indian Ocean Region. Besides, their bilateral relationships have also been upgraded to "global strategic partnerships." Yang (2018) believed that after the Trump government took office, although it raised certain objections to some of the Asia-Pacific Rebalancing Strategy initiated by the Barack Obama administration, and no longer publicly addressed this strategy, the core of this strategy has been retained and renamed as the new Indo-Pacific Strategy.After replacing the Rebalancing Strategy, the Indo-Pacific Strategy has gradually constituted the core of the Asia-Pacific strategy upheld by the Trump administration. 
Zhang and $\mathrm{Li}$ (2016) presented that perhaps there are three following reasons which explain India's doubts toward the Belt and Road Initiative proposed by China. First, objectively, if implemented smoothly, the Belt and Road Initiative will help China strengthen its economic and trade cooperation with the countries along the path, and further consolidate the bilateral relationships between China and the countries along the path.Second, subjectively, India has always considered that it enjoys natural geographical advantages in the regions surrounding the Indian Ocean and South Asia. It is not willing to tolerate the entry of outsiders, such as China, or follow the advance of China. Third, India may use this a bargaining chip in order to request corresponding reward or greater profits from China.Regarding whether India is willing to participate in the Belt and Road Initiative, and strategically integrate with China, according to Ye (2016), although Project Mausam has a certain impact on China's21st Century Maritime Silk Road, based on the national development strategic demands of both countries, the possibility of cooperation between China and India regarding the Project Mausam and the Maritime Silk Road cannot be ruled out.Ye (2016) stressed that regarding India's participation in the construction of theBelt and Road Initiative, China must seek truth from facts, considering the possible benefits from India's participation and recognizing India's suspicious and speculative mentality on this issue.

According to the literature review of Sun (2014), some foreign scholars proposed that China integrates its military bases with the military presences in Thailand (Songkhla), Myanmar (Cocos Islands and Sittwe Port), Pakistan (Gwadar Port), Bangladesh (Chittagong), Sri Lanka (Hambantota Port), Maldives (Gan Islands), Seychelles (Mahe Island) and Sudan (Port Sudan), thus strategically forming a "pearl chain". In particular, Myanmar plans to lease the Cocos Islands to China as its naval base, which will help China to build a "pearl chain" from the South China Sea to the Middle East through the Indian Ocean. The terminal of this "pearl chain" is the African continent. These scholars believed that the proposal of the 21st Century Maritime Silk Road by China in October 2013 actually serves as a cover for the "pearl chain" strategy. Du and Ma (2015) pointed out that the strategic fulcrum of the Belt and Road Initiative is mostly countries that are relatively friendly to China, such as Pakistan. Therefore, China seems to deliberately rule out India due to its own political considerations. As Southeast Asia is the only way to westward expansion, promoting the implementation of the Road and striving for support from countries along the path is naturally a subject that China must work on. However, in India's Act East Policy, Southeast Asia also occupies a very significant position. India has always regarded ASEAN countries as a breakthrough in its entry into the Asia-Pacific region. On the political level, both India and ASEAN regard each other as an important power which they can rely on. In economic terms, India regards Southeast Asia as an indispensable external environment for its own economic development. Regarding security, India's military cooperation with ASEAN has expanded from the initial military exchanges to comprehensive defense cooperation, indicating that the level of cooperation has been upgraded. (Zhang and Chiou, 2012). Lin (2016) pointed out that the power vacuum left by the US-Soviet withdrawal from Southeast Asia has resulted in uncertainty in regional security, while the rise of China has become a potential threat. China's strong territorial proposition in the South China Sea in 1992 triggered regional tension, making the South China Sea one of the conflict regions in the Asia-Pacific region. India has no territorial disputes with Southeast Asia, but is also cautious about China. Therefore, ASEAN has sought to establish close relationships with India. The re-appearance of India is consistent with ASEAN's principle of seeking a balance of great powers, improving maritime security and strengthening the Asia-Pacific multilateral security mechanism (Lin, 2016). In addition, Zhu (2015) presented that India's diplomatic policy toward China faces the following problems: First, the strategic dilemma in which India unites with the United States to contain China, and adheres to the non-alliance diplomacy. Second, the cooperation dilemma of China Threat and the development of economic relationships.Third, the security dilemma from the joint construction of the Belt and Road Initiative and the increase of national security threats. In other words, although the two policies proposed by China and India are considered to be mutually beneficial on the economic level, they are conflicted on the political and military levels. Under tense relationships and conflicts of interests between the two countries, it is difficult to integrate the two policies, making the ideal of Chindia even more out of reach.

\subsection{Trilateral Political and Economic Relationships Among China, India, and Russia}

Fang (2005) investigated the trilateral relationships among China, India, and Russia from the perspective of strategic triangle, and pointed out that the India-Russian relationship is more stable than the Sino-Russian relationship and the Sino-Indian relationship, and that the development of Sino-Indian relationship is far worse than the India-Russian relationship and the Sino-Russian relationship. In other words, the trilateral relationships among China, India, and Russia are like an irregular triangle. As Russia maintains good relationships with China and India, it actively promotes the normalization of the Sino-Indian relationship in order to catalyze the China-India-Russia Strategic Triangle. However, once the three countries are allied, they will face great risks 
and costs if they confronting the United States directly. At present, China, India, and Russia still hope to maintain normal relationships with the United States, and thus will not form a formal group to confront the United States openly and directly. However, the desire of the three countries for greater international influence in the new international order will not suddenly disappear. Therefore, the three countries have not yet ruled out the opportunities to deepen trilateral cooperation in order to defend their common interests (Fang, 2005). Tu (2017) considered that due to the complexity and variability of the strategic triangle, one important aspect of China's strategic planning involves the management of the relationships among the three countries. First, the institutional management of the triangular relationships among China, India, and Russia should be further strengthened. Second, the improvement of the political mutual trust is the basis of the triangular relationships among China, India, and Russia. Furthermore, dealing with the US factor is a challenge for China, India, and Russia. If the China-India-Russia Strategic Triangle is established, it may indeed form an opposition to the United States as described by Fang (2005). However, for China which is fully developing its economy, unreasonably raising the tensions between China and the United States will only affect its economic development. However, as mentioned above, considering the importance of Russia and India to the Belt and Road Initiative, even if the strategic triangle cannot be formed, it is necessary for China to deal with the US factor, strengthen the political mutual trust among China, India, and Russia, and maintain good relationships with Russia along the Belt and India along the Road as mentioned by $\mathrm{Tu}$ (2017).

Chen and Feng (2016) summarized the favorable and unfavorable conditions affecting the development of the trilateral relationships among China, India, and Russia. The favorable conditions include: First, the reform and power transfer of the current international political system are generally beneficial to the expansion and mechanism construction of the trilateral relationships. The macroscopic transfer of international power from west to east forms a macroscopic strategic foundation for the development of trilateral relationships among China, India, and Russia. Second, as the reorganization of power in the Eurasian region is gradually accelerating, urgent international governance needs have arisen from the common surrounding regions of China, India, and Russia. The reorganization of the power structure in Central Asia and South Asia and the fading of the US dominance provide a valuable strategic space for the three countries to expand their influence in the middle of the Eurasian continent, and also requires the strengthening of the strategic communication and policy coordination among the three sides. Third, the changes in the current international situation are conducive to enhancing the cooperation willingness of the three countries. The Ukrainian crisis, the conflict between the Western countries and Russia as well as the sanctions against Russia have forced Russia to shift its diplomatic focus to the East to a certain extent and seek new economic and political cooperation space in the Asia-Pacific region. While promoting the Act East Policy, the Modi government also actively consolidates its bilateral relationships with Russia, China, and other Eurasian countries, and becomes an official member of the SCO. The unfavorable conditions include: First, from the perspective of political systems, the internal differences of the three countries determine that the development of trilateral relationships demonstrates significant exogenous-driven characteristics. Specifically, the mutual strategic demand far exceeds the realistic cooperation foundation, while the lack of endogenous motivation constrains the development of the trilateral cooperation mechanism. Second, from the perspective of national cognition, the three countries are also significantly different in their attitudes toward the development and mechanism construction of the trilateral relationships. Third, from the perspective of regional structure, many structural factors in the political field of the Asia-Pacific region will also directly affect the development of trilateral relationships. Fourth, from the perspective of specific operations, there are still many problems such as insufficient strategic mutual trust and poor cooperation foundation in non-political fields affecting the development and mechanism construction of the trilateral relationships.

The US factor affecting the China-India-Russia Strategic Triangle aforementioned by Tu (2017) can be analyzed from the statement of Zhang and Chiou (2012). Facing the rise of China and the changes in the Asia-Pacific order, the United States announces its return to the Southeast Asia in a high profile, and strengthens its cooperation with traditional allies, such as Japan, Korea, Australia and Philippines. In addition, it urges India to play a greater leading role in Asian affairs. Therefore, India will place more emphasis on strengthening its relationships with Asia-Pacific countries and expanding its influence in the Asia-Pacific region. Besides, Luo (2008) pointed out that in order to prevent China, the United States actively approaches India and attaches great importance to India's position and role in the US rebalancing strategy. Since the Cold War, in order to maintain its global hegemony, the United States has strengthened its bilateral alliance relationships with Japan, Korea, Australia and Philippines in the Asia-Pacific region while improving its relationships with India in order to curb the rise of China and Russia, and attempt to form a mutually balancing pattern among Japan, China, Russia, and India, thereby building a balanced US-led Asia-Pacific region and keeping this region under its control. However, 
according to the literature review of Luo (2014), India and the United States are still only "partners" for now instead of allies. The two countries still face many difficulties in establishing future alliances. First, India has long pursued a non-alliance diplomatic policy, and practices have proved the non-alliance diplomatic policy has enabled India to have its bread buttered on both sides and win a broad diplomatic space for India. India will not easily abandon this diplomatic tradition through which it can gain both international reputation and real benefits. Second, if India is aligned with the United States, its strategic partnership with China is bound to disintegrate, which is unacceptable for India as China has an increasingly broad strategic and economic interest in the eyes of India. Third, although the United States and India are carrying out comprehensive cooperation, the two countries have discrepancies on issues such as nuclear non-proliferation, intellectual property rights, human rights, economic and trade cooperation. In particular, it is difficult to reconcile the conflict between the United States and India in the leadership of the Indian Ocean. In other words, if the relationships among China, India, and Russia are like an irregular triangle as described by Fang (2005), the relationships among China, India, Russia, and the United States are like an irregular quadrangle. This quadrangle not only symbolizes more complicated relationships but contain greater tensions and severer frictions. As the biggest variable in the quadrangle, if the United States approaches India to check and balance China facing the rise of China at present, in the face of future rise of India, the United States presumably will propose the India Threat Theory and approach one certain country to check and balance India. But in such circumstances, China must still balance these countries, actively promote mutual trust and benefit, and seek common ground while reserving differences. Only when the four sides can obtain benefits simultaneously will the Belt and Road Initiative be smoothly implemented without being hindered by the United States, Russia, and India.

\section{Results and Discussion}

To sum up, the connection with Russia and India is mutually beneficial in economic terms. However, in political and military terms, Russia and India have doubts and are not actively involved. In particular, out of political and military considerations, India would rather sacrifice its own economic interests than cooperate with China. If all the great powers only consider their own interests, they will not support or even obstruct the Belt and Road Initiative. On one hand, under the banner of Asia-Pacific Rebalancing, the United States which employs political power in the east to instigate Japan and other Asian allies to check and balance the Belt and Road Initiative is certainly the biggest obstacle. On the other hand, the two countries close to the north and south borders of China can affect or hinder the smooth implementation of the Belt and Road Initiative in the most direct manner. The Eurasian Economic Union proposed by Russia and the Project Mausam launched by India are clearly targeted at the Belt and Road Initiative. The Eurasian Economic Union led by Russia can help Russia maintain its leading position in the regional economy, and confront with the European Union. In addition, Russia can also maintain its political influence in Central Asia and then exert influence on the Belt and Road Initiative. For the consideration of economic interests, connecting the Eurasian Economic Union with the Belt and Road Initiative is beneficial for both China and Russia. In addition, the Project Mausam launched by India is only a product of India to counter the Belt and Road Initiative under the mentality of "great powers". Based on the above analysis and the views of many scholars, if India can get rid of its mentality factor and rule out political considerations, actively participating in the Belt and Road Initiative or even connecting with the Project Mausam will yield the greatest economic benefits for both China and India on the economic level. Although Chen (2015) pointed out the possibility of connecting the Belt and Road Initiative with the Project Mausam and the Eurasian Economic Union, but due to the different considerations of the three countries, there are still many problems which cannot be solved. According to Hu et al. (2015), compared to India, Russia has a higher possibility for cooperation or connection. The greatest goodwill of India is that it does not obstruct the Belt and Road Initiative, not to mention cooperation or connection. Even in this circumstance, China must circumvent in the irregular triangle or the irregular quadrangle and try to maintain good relationships with each side. The initial start of the Belt and Road Initiative has met with the great pressure from the United States (east), Russia (north), and India (south). As China has recently been hit by the trade war, it has been actively looking for allies and seeking assistance from India and Russia in order to break through the US trade blockade. The three-party talk between China, India, and Russia at the G20 summit held in Japan in June 2019 seems to have opened up opportunities for future cooperation among the three countries. But overall, there is an extremely hard and long way to go for this key westward development policy of China.

\section{References}

Chen, D., \& Feng, S. (2016). RIC Cooperation in the Context of Systemic Changes: Status Quo, Conditions, and Prospects. Global Review, 45(6), 1-18. Retrieved from

http://www.siis.org.cn/shgjwt201512107417/UploadFiles/file/20161223/201606002\%20\%E9\%99\%88\%E4 
$\%$ B8\%9C\%E6\%99\%93.pdf

Chen, F. (2015). Research on the Strategic Connection of the Belt and Road Initiative and India's Project Mausam. Global Review, 2015(6), 15-32. https://doi.org/10.13851/j.cnki.gjzw.201506002

Chen, M. (2009). Territorial Sovereignty and Regional Security: An Analysis of China-India Border Dispute. Taiwan International Studies Quarterly, 5(1), 157-183. Retrieved from http://www.tisanet.org/quarterly/5-1-7.pdf

Chen, M. (2013). Indian China Policy: An Analysis of Its Factors and Decision-making Process. Taiwan International Studies Quarterly, 9(3), 155-173. Retrieved from http://www.tisanet.org/quarterly/9-3-8.pdf

Chi, F., \& Ji, X. (2015). Research on the Connection and Cooperation between the Silk Road Economic Belt and the Eurasian Economic Union. Russian, East European \& Central Asian Studies, 2015(4), 34-40. Retrieved from http://www.oyyj-oys.org/UploadFile/20150113002/2015-08-05/Issue/xtlgtdud.pdf

Du, D., \& Ma, Y. (2015). One Belt and One Road: The Grand Geostrategy of China's Rise. Geographical Research, 34(6), 1005-1014. https://doi.org/10.11821/dlyj201506001

Fang, T. (2005). An Assessment of the Development and Possibilities of a China-India-Russia Strategic Triangle. Prospect \& Exploration, 3(5), 20-33. Retrieved from https://www.mjib.gov.tw/FileUploads/eBooks/0c32ba8f559b4d2ca8a5a80e0ca0493d/Section_file/bd0f1961 434b432f91c24161d2d4e8f1.pdf

Hu, Z., Liu, W., \& Song, T. (2015). Inter-Subjectivity Consensus, Geopolitical Structure and Building the One Belt and One Road. Tropical Geography, 35(5), 621-627. https://doi.org/10.13284/j.cnki.rddl.002766

Jia, C., \& Chen, Y. (2015). Relationships among China, the United States, and Russia from the Perspective of the Game Theory: New Trend and Operational Ideas. Asia-Pacific Security and Maritime Affairs, 2015(2), 59-70. Retrieved from http://mall.cnki.net/magazine/Article/YFZH201504005.htm

Li, L. (2015). International Industrial Planning and the Bottleneck for Development along the Silk Road Economic Belt. Urban Insight, 2015(1), 5-12. https://doi.org/10.3969/j.issn.1674-7178.2015.01.001

Lin, Y. (2016). The Reconstruction of India's Security Role in Southeast Asia: Toward "ASEAN-centric" Orientation. Review of Global Politics, 53, 83-118. https://doi.org/10.29899/JRM

Lou, C., \& Zhang, M. (2010). Strategic Importance of South Asia and China's South Asia Strategy. Contemporary International Relationships, 2010(2), 42-47. Retrieved from http://xdgjgx.qikann.com/

Lu, S., \& Wang, S. (2016). Review on the Research Achievements of the Belt and Road Initiative. Russian, East European \& Central Asian Studies, 2016(5), 132-151. Retrieved from http://www.oyyj-oys.org/Magazine/Show?id=35446

Luo, H. (2008). The Diplomacy of Balance in America's Foreign Strategy. Journal of Social Science of Hunan Normal University, 2008(2), 52-56. Retrieved from http://www.airitilibrary.com/Publication/alDetailedMesh?DocID=hnsfdx-sh200802012

Luo, H. (2014). On the triangular relationship between China, America, and India since the US Pivot to Asia. Journal of Central South University (Social Science), 2014(6), 177-182. Retrieved from http://www.airitilibrary.com/Publication/alDetailedMesh?DocID=zndxxb-shkxb201406028

Men, H. (2017). Rise of China and Reform of International Order. Quarterly Journal of International Politics, 1(1), 60-89. Retrieved from http://www.imir.tsinghua.edu.cn/publish/iis/7238/20160307/98431457317250194.pdf

Meng, Q. (2017). Viewing the Dong Lang Confrontation through India's Mentality. Journal of Boundary and Ocean Studies, 2(5), 21-34. Retrieved from http://www.cibos.whu.edu.cn/res/soft/2017/ea88cba98bd4017c.pdf

Sun, D. (2014). Flexible Military Presence of China in the Middle East in the New Era. World Economics and Politics, 2014(8), 4-29. Retrieved from http://mideast.shisu.edu.cn/ca/21/c3996a51745/page.htm

Tu, C. (2017). Triangle of China, India, and Russia: Theories, Conditions and Changes. Russian, East European \& Central Asian Studies, 2017(4), 87-100. Retrieved from http://www.oyyj-oys.org/UploadFile/Issue/dig2ov5j.pdf

Wan, Q. (2016). Analysis of the Dilemmas Facing Current Eurasian Economic Union-Connection with the Silk Road Economic Belt. Eurasian Economic, 2016(2), 54-61. Retrieved from 
http://www.oyjj-oys.org/UploadFile/Issue/uglz3bg5.pdf

Wei, B. (2017). Russia's Geostrategy: View of Eurasian Economic. Journal of Eurasian Studies Quarterly, 1, 41-46. Retrieved from http://readopac2.ncl.edu.tw/nclJournal/search/detail.jsp?sysId=0006951628\&dtdId=000040\&search_type=d etail\&la $=\mathrm{ch}$

Wei, L. (2017). Analysis of India-Japan Active Diplomacy with the Rise of China. Journal of Dali University, 2015(1), 85-88. Retrieved from http://www.airitilibrary.com/Publication/alDetailedMesh?DocID=dlxyxb201301024

World People News. (2017, May 18). India and Japan Jointly Promote the Free Corridor to Counter the Belt and Road Initiative. Retrieved September 10, 2019, from http://www.worldpeoplenews.com/content/news/13609

Wu, Z. (2015). Strategy Development, Objectives and Implementation Path of India in the Asia-Pacific Region. South Asian Studies, 2015(4), 98-121. Retrieved from http://www.airitilibrary.com/Publication/alDetailedMesh?DocID=nyyj201504007

Yang, J. (2018). China's Major Country Relationships and Periphery Maritime Strategies: Dealing and Shaping in the New Era. Journal of Boundary and Ocean Studies, 3(1), 14-23. Retrieved from http://www.cibos. whu.edu.cn/index.php?id=867

Yang, L. (2016). Establishment, Practice, and Impact of Greater Eurasian Partnership by Russia. Eurasian Economic, 2017(6), 57-72. Retrieved from http://www.oyjj-oys.org/UploadFile/Issue/z5zfloug.pdf

Ye, H. (2016). South Asia Strategy of India and Its Impact on China's Promotion of the Belt and Road Initiative. Indian Ocean Economic and Political Review, 2016(2), 4-15. https://doi.org/10.16717/j.cnki.53-1227/f.2016.02.001

Zhan, Y. (2017). Silk Road Economic Belt and Eurasian Economic Union: Difference and Connectivity. International Economic Review, 2017(4), 149-160. Retrieved from http://big5.oversea.cnki.net/kcms/detail/detail.aspx?dbCode $=$ cjfd\&QueryID=14\&CurRec=11\&filename=GJ PP201704011\&dbname $=$ CJFDLAST2017

Zhang, K., \& Chiou, C. (2012). New Thinking on the Act East Policy of India. International Studies, 2012(4), 90-103. Retrieved from http://www.airitilibrary.com/Publication/alDetailedMesh?DocID=gjwtyj201204010

Zhang, L., \& Li, P. (2016). Cognition of India toward the Belt and Road Initiative and the Countermeasures of China. South Asian Studies Quarterly, 2016(1), 18-38. Retrieved from http://www.airitilibrary.com/Publication/alDetailedMesh?DocID=nyyjjk201601003

Zhu, C. (2015). Dilemmas and Strategic Options vis-à-vis India' s China Policy under the Modi Administration. South Asian Studies Quarterly, 2015(3), 8-10. Retrieved from http://www.airitilibrary.com/Publication/alDetailedMesh?docid=nyyj201503001

\section{Copyrights}

Copyright for this article is retained by the author(s), with first publication rights granted to the journal.

This is an open-access article distributed under the terms and conditions of the Creative Commons Attribution license (http://creativecommons.org/licenses/by/4.0/). 